\title{
衝撃加振時のバイト振動と工具摩耗の 相関性に関する研究*
}

\author{
村 田 良 司** 小久保 邦彦***
}

Correlation between Flank Wear and Tool Vibration Excited
by a Diagnostic Impulse in Machining Process

Ryoji Murata and Kunihiko Kokubo

\begin{abstract}
For finding new in-process monitoring methods of tool function, the present paper treats about constraint effects of tool wear on transient vibration generated by calibrated force in turning operations. The definite impulse force in feed direction is made by hammering on the side face of the tool with a pendulum. The impulse is always calibrated with a piezoelectric force sensor located on the hammer. The tool vibration is detected with an acceleration sensor. The power-spectrum of the transient vibration is carefully examined for seeking correlation with flank wear. Similary, impulse in powerforce direction is also tested. Major findings of the study are as follows: 1) The first mode of resonance frequency $f_{1}$ of the tool is mostly dominant in the power-spectrum, and the amplitude of $f_{1}$ has fairly close correlation with flank wear. 2) Correlation between vibration in power-force direction and flank wear is also verified. 3) It is confirmed that the effect of the impulse on the machined surface is negligibly small.

Key words: flank wear, in-process sensor, transient vibration, diagnostic impulse, vibration analysis
\end{abstract}

1. ま ¿ がき

切削加エシステムの高度自動化のためには，工具摩耗の自動 監視システムが不可欠である。このようなシステムの確立に寄 与するため，看々のインブロセス工具席耗センサが提案され， 多くの研究がなされてきだ21。これらはそれぞれ興味ある成 果をもたらしたが，なお原理的にも現象的にも確実なセンサ方 式がなく、まだまだ研究の樌み重ねが必要な状況にある。本研 究は [切削中の工具に微小振動を与之,そのレスポンスから工 具の摩耗状況を推定しようとする研究]の一愣であるが，本報 ではまずこの方式の可能性を枱討する。

\section{2. 序諞}

バイトホルダに固定されたシャンクは，非切削時（非切込み 時）には一端固定 ·他端自由の片持ちはりとみなしうる。 又， 切削時には切れ刃部は被削材と結合するので, 工具に何らかの 拘束があるが、この拘束は基本的には望性的な拘束であって振 動を直接抑制するものではないろい。しかし，工具耗が発生 した場合には弾性的，席撩損失的な拘束が增加するので工具の 振動が抑制されるものと考えられる。例えば，バイトに送り方

\footnotetext{
*原稿受付 平成 5 年 5 月 25 日

**正会员 東京理科大学理工学部 (野田市山崎2641)

***正会員シチズン時計（株）（所沢市下富840）
}

向から整を加える場合，バイトは送り方向に振轩するわけで あるが，逃け面麻耗の增大にともない逃け面度耗良と被削材と の接触している面糟が大きくなり，接触損失が增す。この損失 によって，バイトの 1 次モードの振動に相当する成分は相応し て小さくなる。さらに、バイトを主分力方向に加振するときで

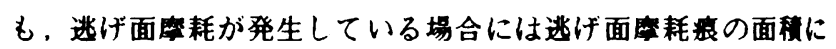
比例する力が作用し，やはりバイトの振䡃は抑えられると考え られる。

本研究は以上の見地に立って，主として実酸によって現象を 分析し、渻加振時のバイト振動と工具耗の相蔺性を明らか にしようとするものである．また，逃げ面摩耗がある程度をこ えて堷加すると，条件によってはびびり振動を発生する场合も ありうるが、本研究ではこのような切削条件は対象としない. なお本報の実㤨範囲では，いわゆるびびり振䖝を全く諗めなか つた。

$$
\text { 3. 実䱾方法 }
$$

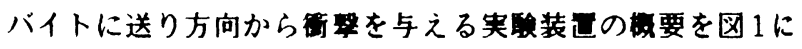
示す.この装亚は，振り子式のハンマによってパイトに㹕力 を与える仕組みとなっている，ハンマは一度渻突した後に，路 ね返って再箸突するが，二度目以降の衙笑による力は一度目の 得力と比べて十分に小さく，また再箸笑するまでの時间に比 べFFTのデー夕取込み時間（10 m s) を短く設定するので

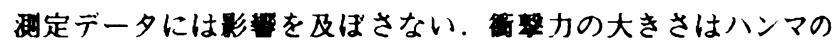
振り上げ角によって自在に調節することができ，与えた霜軎力 


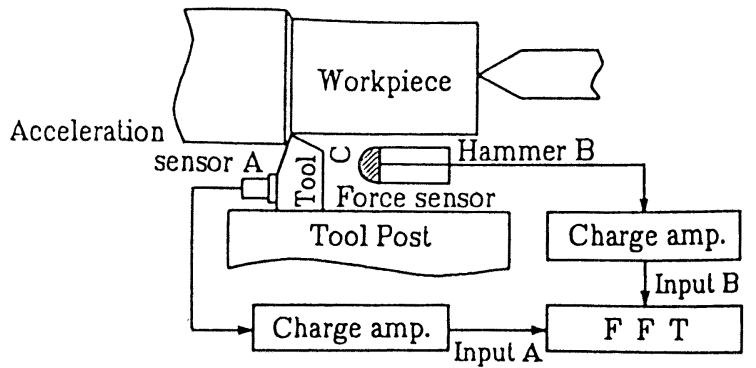

Fig. 1 Experimental apparatus

Table 1 Cutting conditions

\begin{tabular}{l|l}
\hline Tool & Carbide P20 $(0,6,5,6,15,15,0.8)$ \\
Material cut & $0.35 \%$ C Carbon steel) \\
Cross section of shank & $19 \times 19 \mathrm{~mm}$ \\
Tool extention & $30 \mathrm{~mm}$ \\
Depth of cut & $0.5-2.0 \mathrm{~mm}$ \\
Feed & $0.05-0.15 \mathrm{~mm} / \mathrm{rev}$ \\
Cutting speed & $80-140 \mathrm{~m} / \mathrm{min}$ \\
Cutting fluid & Dry \\
\hline
\end{tabular}

の大きさはハンマに内蔵されている圧電式のセンサによって測 定することができる。

工具はP 20 スローアウェイチップを用い，切れ刃部に，研 削によって任意の人工选げ面摩耗を付けたものを数種類用意し た。なお耗部の当たりを良くするため実驗前に，通常の自然

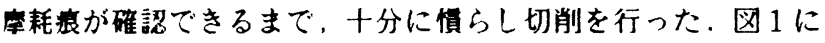
おいて，バイトは主分力, 送り分力方向とも強固に固定されて いる．実驓条件は表1に示す通りである。

切削中のハイイトに图1に示した装置で送り方向から衝慗を 加之，生にた過渡振動を加速度計 Aによって娭出する，その出 力信号をF F Tによって分析する．模討は主としてバイトの 1 次モードの固有振動数に相当するピーク f1 (困3㐱照)につ いて行った。なお，本実䮴での非切削時の信号の安定性は 0. $5 \mathrm{~dB}$ 程度である。

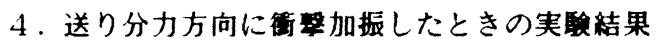

\section{1 耗幅の增加に対する波形の変化}

冈2，図3は加速度信号の波形とそのスペクトラムの应耗幅 による变化を例示したものである．図2において非切削時に加 振した時の過渡振動と切削中に加振した波形を比べると，切削 中の方が娍衰奻果が大きくなっているということが分かる．ま た，過渡振動の振幅が多少ビートを起こしているのはバイトの 送り方向の振動の一次モードの固有振動数と主分力方向のそれ が雪めて近いためである。

龱3において，バイトの1次モードの固有掁動数に相当する 周波数 $\mathrm{f} 1 の$ 振幅は，耗幅の堷加によって小さくなって行く ことがわかる。また，ピーク $\mathrm{f} 2$ は摩耗の增加によりスペクト ラムのバワーの中心が周波数の高い方へ移行した結果, 隆起し たピークである。

4. 2 加振力を変化させたとき

加振力によって耗幅と振幅との相関性がどのように変化す

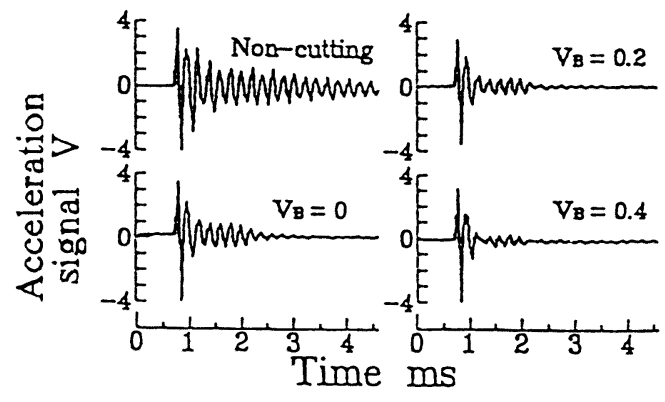

Fig.2 Examples of wave-forms

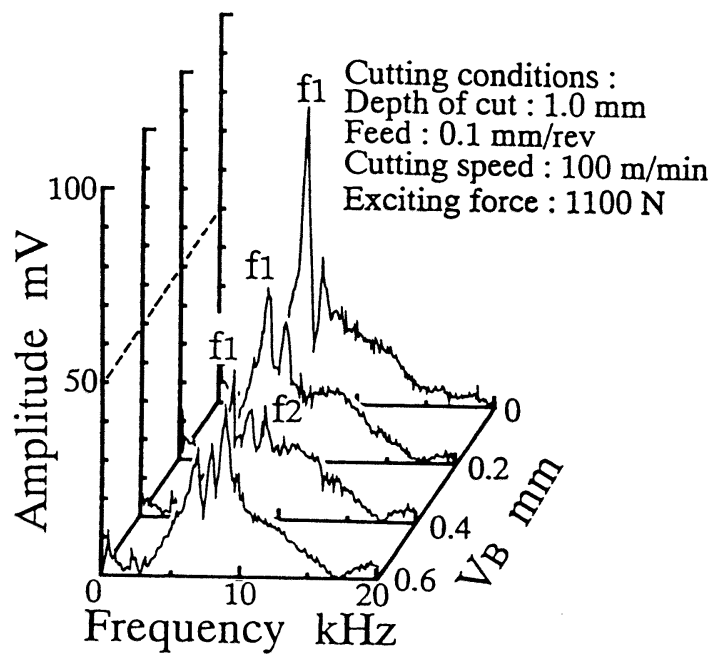

Fig. 3 Effect of flank wear on spectrum

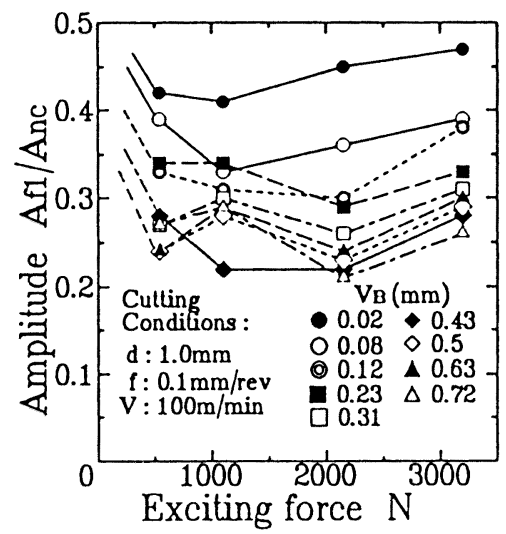

Fig.4 Effect of exciting force

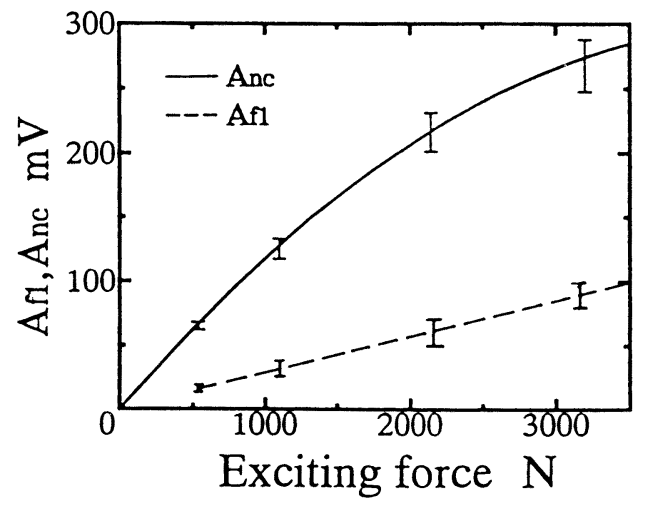

Fig.5 Relationship between exciting force and Af1,Anc 


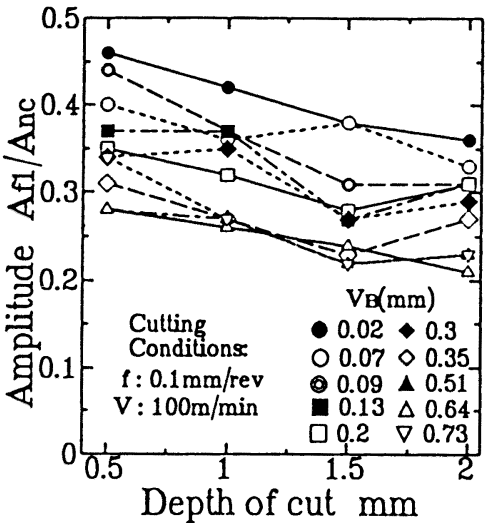

Fig.6 Effect of depth of cut

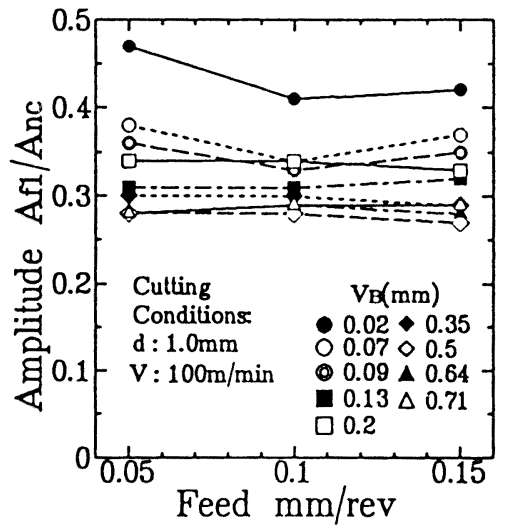

Fig.7 Effect of feed

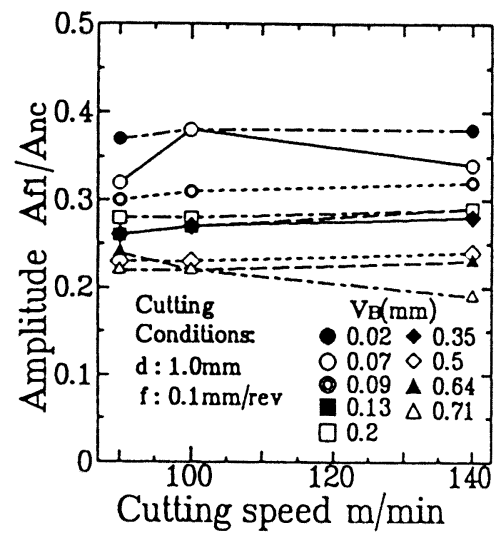

Fig. 8 Effect of culting speed
るかを調べた結果を図4 に示す，困の継軸の振幅は，切削中の f1に相当する振幅值Af1を，切削していないときのf 1 (これ

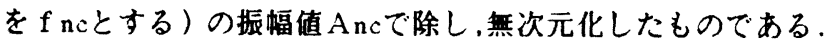
図から加振力の增加に対して振幅比は多少增加するが，同時に 加振力が十分小さいときもやや堷大する㑯向が認められる。こ のような現象を引き起こす原因について考える．非切削中のバ イトを箸慗加振した時の加振力と振幅 Ancとの関係（図５）を みると，加振力がある程度以上大きくなるにつれて Ancは加振 力に対して線形ではなく，多少能和的な挙動を示す．なおAf1 は実䮲筑囲ではほぼ線形であった。したがって，加振力が大き くなると振幅比が見かけ上增加するものと解釈できる．さて， 一般にAf1は加振力に比例的な過渡振動と，加振力に無関保な 加工中のノイズに含まれる $\mathrm{f} 1$ の成分との和である。これ対 し、Ancは加振力比例項（加振力小の場合）のみであるから， 加振力が十分小さくなると，振幅比 Af $1 / \mathrm{Ancが}$ 再び大きくな るものと考えられる。しかし，加振力が小さくなると，加工に 伴うノイズ項の影韫が大きくなるため，摩耗幅によるAf1の変 化も測定しにくくなると考えられる.

本研究の目的には，ノイズの影雾を受けにくく，かつ加振力 と振幅 Ancがほぼ線形性を示す加振力のレベルが適当である. したがって、以下，1100Nの加振力で実騏をおこなう．

4. 3 切削条件を変化させたとき

次に，切削条件を变化させたときの选け面虖耗幅とバイト振 幅比Af1／Ancとの関係を調べた結果を示す.

图6は切込み量を変化させたときのものである．切込み量が 大きくなるにつれて振幅のレベルは小さくなることがわかる． これは，切込み量が增えると，摩耗幅が同一であっても被削材 と逃げ面の接触する面積が增え，パイト振動系の㓮性と損失が 大きくなるためであると考えられる．また，すくい面での切り くずとの摩撩力が，切込み量の增加によって增し，減衰奻果が 增すことも考えられる。しかし，図7から送りの影響を受けに くいことが分かるので，すくい面の席攃力による減衰奻果は小 さいと言える。

図7は送り，図8は切削速度をそれそれ変化させたときのグ ラフである．これらの図より，送りを変化させたときや，切 削速度を変化させた場合，振幅比 Af1/ Ancには大きな变化 はみられない。

以上より，f1の振幅と耗幅との相関性は，送り量や切削 速度に依存しないが，切込み量によりかなりの陟算を受けるこ とが碓かめられた。

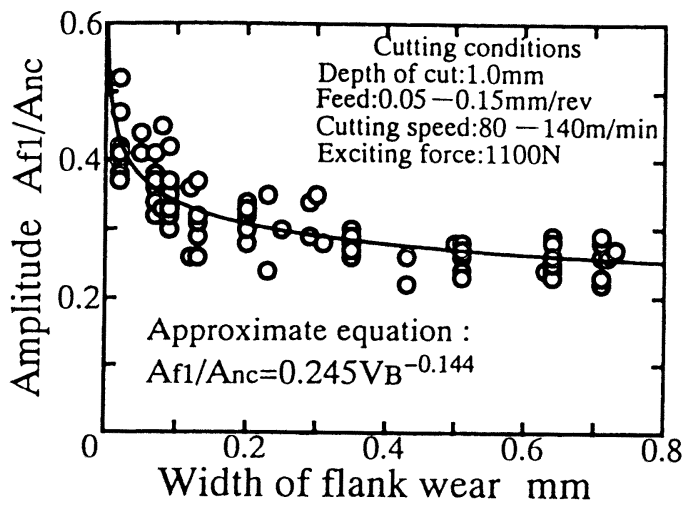

Fig.9 Relationship between width of flank wear and Af1/Anc

4. 4 相関関保の近似式

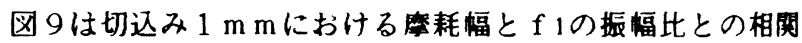
性を示したものである。この図より各デー夕は全体として一定 の関数阅係にあるものと考えられる，べき乗関数モデルをあて はめて，この相関関倸を近似したとすると

$$
\mathrm{Afl} / \mathrm{Anc}=0.245 \mathrm{VB}^{-0.144}
$$

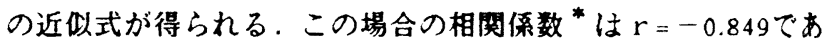
る。よって，耗幅と $\mathrm{f} 1$ の振幅との间には強い相阙性が認め られることがわかる。

過渡店答のスペクトラム（図3）より，整耗幅の増大に対し てもf1の值はあまり変化しないことが分かる。しかし，耗 幅が大きくなるにつれて，fははわすかに增加する。これは接 触㓮性の堷加による影整と考えられる。また，スペクトラムの 最大值をとるピークはf1より大きな周波数へと移っていく. すなわち，過渡振動の主なパワーがf1より高い周波数带城へ 移行してきていることを示している。この㑯向を量的に評洒す るため, $9000 \mathrm{~Hz}$ 付近の目立ったピークを $\mathrm{f} 2$ とし，f1との振 幅比（Af1/Af2）に着目して，选げ面麻耗幅の增加による変化

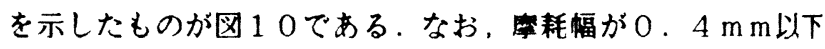
のときは，f2が硯現していないが，その場合 $9000 \mathrm{~Hz}$ 付近の 值をとった．またこの場合，切込み $1.5 \mathrm{~mm}$ 以上において， 強い相并性がみられるので，図は切込みが $1.5 \mathrm{~mm}$ 以上のテ 一夕を示してある。

* 近似式が直線になるような冏数グラフ（上式の埸合は両対 数グラフ)上における相关係数を言う。 


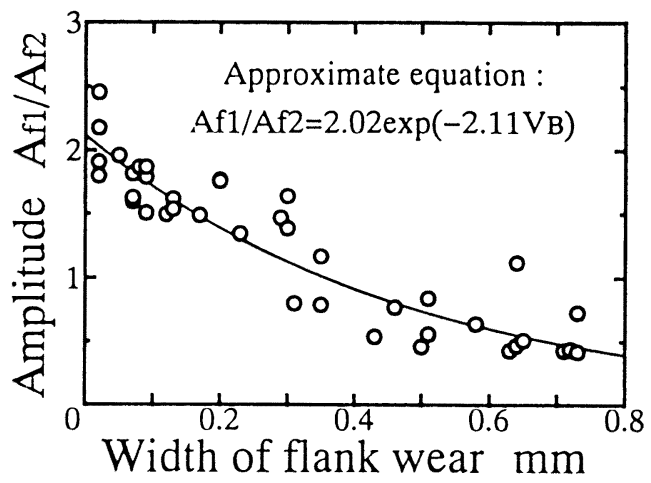

Fig.10 Relationship between width of flank wear and Af1/Af2

Cutting conditions are same as Fig.9

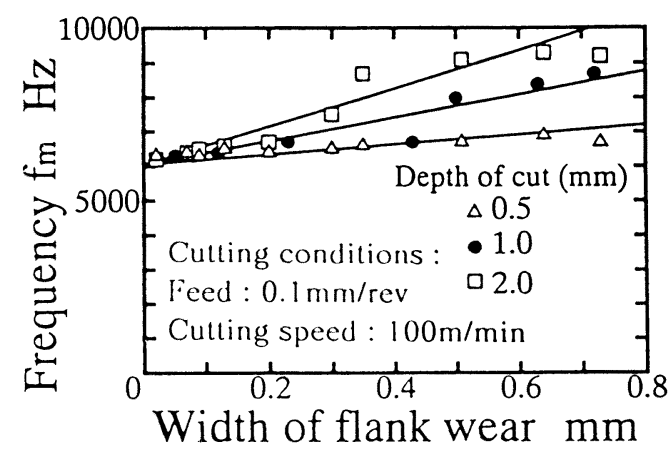

Fig.11 Relationship between width of flank wear and $\mathrm{fm}$

指数関数モデルによりこの相関関係をあてはめると

Af 1 Af $2=2.02 \exp (-2.11 \mathrm{VB})$

なる近似式が得られた（但しこの场合の相网係数は $r=-0.912$ である).

4. 5 周波数による度耗幅推定

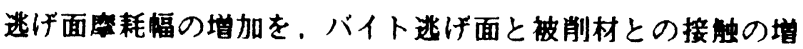
大によるピーク周波数の变化から推定できるか否か唉討した.

通常，バイトを符加振したときの過渡振動のスペクトラムを 見ると，加工に伴うノイズの影璘や刃物台の共振等により複数 のピークが複雑に発生するので，そのままでは特定の周波数の わずかな增加を正碓につかむことが困奞である。この場合，， イスの彭笪は時間的にはぼ一定であるが，过渡振勃は急速に娍

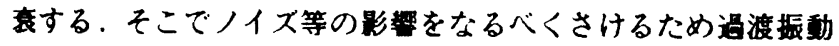
の初期摄幅（ここでは3サイクル分とする）のみを取ってフー リエ婪损して唉討する．そのスペクトルの取大ピークの周波数 $\mathrm{fm}$ と耗幅との関係を図 11 に示す．f $\mathrm{m}$ 增加量は大きく はないが，蒌什面摩耗幅におおむね比例的に增加することが明

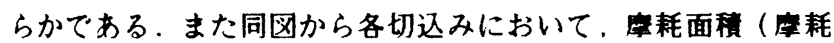
愊 $\times$ 切迈み）が同じならば，周波数 $\mathrm{f} \mathrm{m}$ ははば同じ值になるこ とが分かる。

なお，周波数 $\mathrm{fm}$ m，信号取込み時间が短い（6 $6 \mathrm{k} \mathrm{z}$ の场 合， $0.5 \mathrm{~m} \mathrm{~s} ）$ ため。周波数分解能が多少阻富されるのでスペク トルの最大ピークの周波数 $\mathrm{f} \max$ そのものを正碃に表現するも のではない．これは，むしろ，ささいな $\mathrm{f} \max の$ 変䡃にとらわ れない平均的な変化を示している。つまり，f $\mathrm{m}$ が增するこ

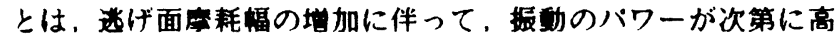
周波娍に移行することを示している．このことは，4．4 項で

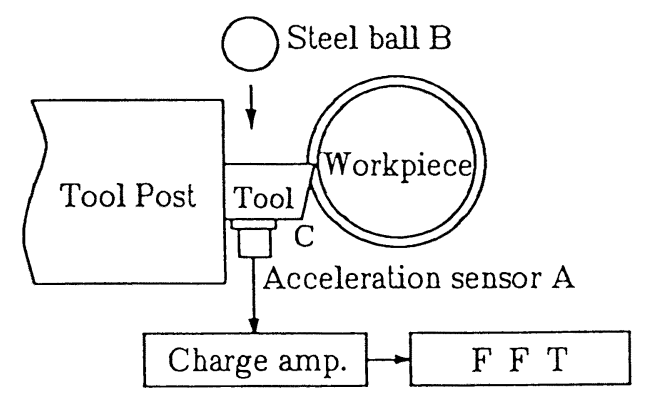

Fig.12 Experimental apparatus

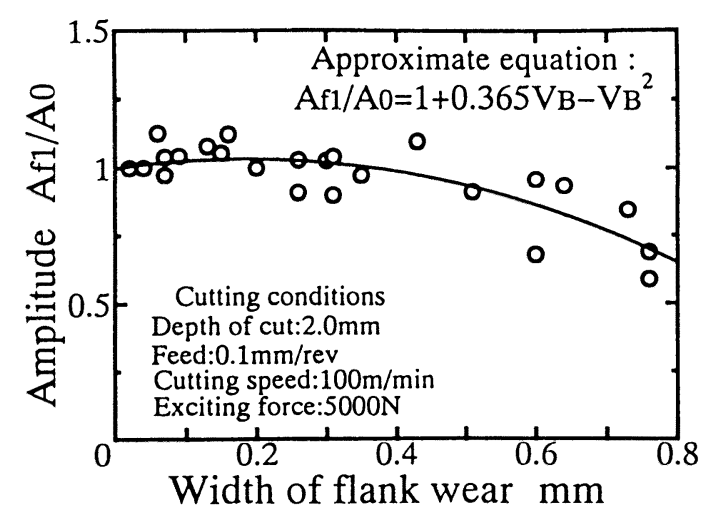

Fig.13 Relationship between width of flank wear and Af1/A0

述べた事実と同梄な結果である。

本項のようにスペクトル自体の最大ピークの周波数 $\mathrm{f} \max$ よらず $\mathrm{f} 2(4.4$ 項)，f $\mathrm{m}$ ( 4.5 項) を対象として娭討し た理由は，自動的な工具寿命判定に応用する場合の便宜を考之 たからである

すなわち，f maxは定莪としては明確であって，すっきりし ているが, 実险的には種々の原因から複雑な变要をする可能性 がある，かつ，その值は事前には当然に未定であるから，その 周波数を対象として自動判定回路を棈成する埸合には困競があ る。

これに対し，f 2はある程度アブリオリに定めておくことが 可能であるので判定回路などの榑成がそれだけ容易である。 ま た，実卧的に見て，f $\mathrm{m} は$ はイスの影第が比㜞的少ない等の利 益があると考えられる。

以上のことより，周波数変化との䦐係によっても度耗幅が推 定できる可能性があると考える。

\section{5.落球テストによる結果}

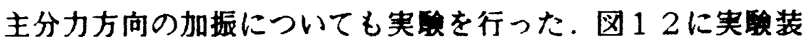
雷を示す。

この実覽において，バイトの突出し長さは横方向加振の埸合 と同しで、算量 $30 \mathrm{~g}$ の球 $\mathrm{B}$ を決められた高さから落下させ， バイトCの振動を見ようとするものである．佣球を落下させる 高さは粎60〜460 m mの策囲で行った.

前出の送り分力方向の実䮲と同漛にバイトの振動は加速度計 によって検出され，FFTにより解析を行う。また球は一度 筑突した後，跳返って再衙突を起こす。しかし，再箸突を起 こすまでの時間は，F F Tのデー夕取込み時間（10 m s ）よ 


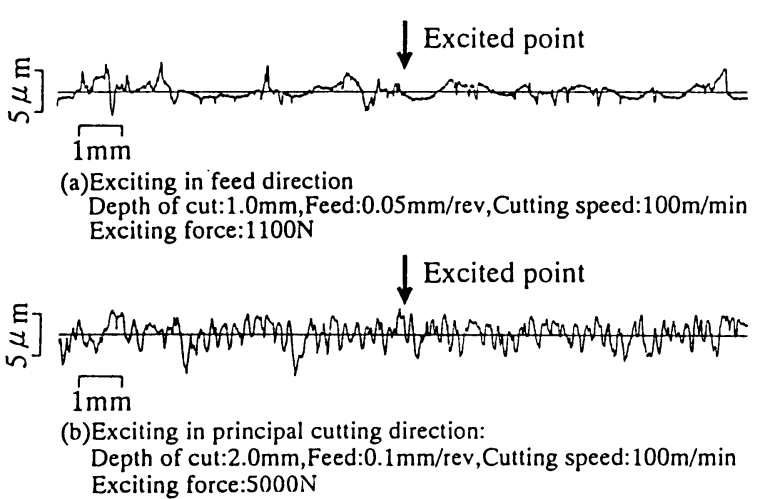

Fig. 14 Effect of impulse on surface roughness

ク十分に長いのでデータに影䇠を与えることはない。ここで， 衝繋力の大きさは，バイトに制球を落下させたときにできる圧 痕の大きさと制球の反発係数を湘定することにより見皘もった 值である。なお，本実駩での信号の安定性は非切削時で 0.5 $\mathrm{d}$ B 程度である。

この実険において，加振力が大きすきると，仕上面に与える 損賃が問題となるおそれがある。また，加振力が小さすぎる場 合には加工中に発生するノイズの影響などにより，庳耗幅によ るf 1の振幅変化が測定しにくくなる.

以上のことを考虑した結果，加振力が $5000 \mathrm{~N}$ の時が䝵当であ ると考えられたので，この加振力について実験をおこなつた。

逃面摩耗幅とf1の振幅との相関性を示したものを図 13 に示す、この图を見ると摩耗幅が大きくなるにつれて振幅比が 徐々に小さくなる傾向が見受けられる：二次関数モデルを用い てあてはめを行った場合、

$$
\text { Af1 } \mathrm{A} 0=1+0.365 \mathrm{VB}-\mathrm{VB}^{2}
$$

となり、相関係数は $\mathrm{r}=-0.760$ となった。なお $\mathrm{A} 0$ はVB=0 の掁幅である．このことより主分力方向の加振においても，选 げ面摩耗幅とバイトの 1 次モード $\mathrm{f} 1$ に相当する振幅との間に は，一応の相関性がみられると言える。

\section{6. 加振の仕上面に対する影䉡}

切削中のバイトを加振することにより仕上面にどのような影 整を及ばすかについて述べる。

本実险において简撃力を送り分力,主分力方向から加えたが， 肉眼により確認した結果，仕上面に与える影翌は認められない。
また，箈慗を加えることによりチッフに損などが発生するこ ともなかった。

さらに，加振による仕上面の粗さへの影整を調バるために， 表面粗さを調べたものを图 14 に示す．罒の（ａ），(b)はそ れぞれ送り分力方向，主分力方向に加振したときのものである． 加振条件は本実梌において相関性が強く碓認できた条件につい ておこなっている。この图を見ると、最大粗さRmaxは加振し たことによって、非加振時に比へ大きくなるということはない，

以上から，本実联の管囲内においては，送り分力方向，主分 力方向ともに工具を加振したことによる表面粗さへの影敏は認 められない。

$$
\text { 7. 結論 }
$$

本実騦より以下の結果を得た。

(1)バイトを送り分力方向に嶆加振した睆のバイトの 1 次 モードの振動と逃げ面摩耗幅の間には強い相関性があり， これから逃げ面庫耗幅の推定が可能と考えられる．その相 関性は加振力，切込みの影を受け，送りや切削速度に影 霎されない

(2)ハイイトを主分力方向に加振した場合も，本実险の籍囲内 において相関性を確認することができた。

(3) 本実㙂の筙囲内では加振による仕上面への影管は全く認 められない.

本研究の実験を担当された山本正弘氏（本学卒研生）に感腤 する。

本実聡で，表面粗さを测定するにあたってご助力頂いた小坂 研究所の小美湍氏，荒木氏に厚く御礼申し上げます．

\section{李考献}

1) G.F.Micheletti,et al.:In Process Tool Wear Sensors for Cutting Operations, Ann.CIRP, 25,2 (1976) 483 .

2)上原邦雄: 切削加工用七ンサ、日本機械学会誌,89,9 (1976) 1084 .

3) 中山一雄,新井実,舆野耕司: 切削工具摩耗のインプロセ 又测定,昭和 52 年度精機学会秋季大会学術㴔演会前刷， (1977) 102 .

4) 村田良司,大岛郁也,前川克廣：切削工具の加振特性と工具 損賃, 1990年度精密工学会春季大会学術語演会諑演論文集, (1990) 821 . 